\title{
A Quality Matrix to Improve the Knowledge Product Management
}

\author{
BOCA, Gratiela Dana \\ Technical University Cluj Napoca, Cluj-Napoca, Romania \\ North Center University Baia Mare, Faculty of Sciences, Romania
}

\begin{abstract}
The paper presents a quality matrix, some strategies and different tools for product evaluation using IT programs. The paper presents some solutions obtained with different programs and the influence upon the life cycle of the product, especially from design stage of technological manufacturing until the product decline. The development of a new product by a company begins when the need to create a new product appears: a new technology, the appearance of a competitive product or a change in the existing legal framework and is completed with the final introduction of the product in the market. These new products may be based already on another existing products based on new technology without the need of support from others. A company decision to develop a new product is probably one of the most important decisions to be made in the history of that company, because a new product development is directly linked with the development and the evolution of that company. The types of companies to which design and development techniques are best applied are those which design and manufacture their own products, and in which competitiveness is described by factors such as: quality, price, functionality, development time, commercialization time.
\end{abstract}

Keywords: life cycle, quality, knowledge process, design.

\section{Introduction}

As many companies have demonstrated over time, product design contributes greatly to the improvement of competitiveness, because it permits reduction of costs, increase of quality, and often, shortening of the time necessary to get the product on the market.

In manufacturing enterprises, the product knowledge is distributed across the whole company.

This knowhow represents an essential resource for successful competition in the market and should therefore be preserved and used as efficiently as possible.
A way of reaching this goal exists in the use of knowledge-based systems which contain accumulated product knowledge on different aspects during the product life cycle, design, manufacturing, usage and recycling (Klepper, 1996).

Besides, product data modeling and management has become more and more an important feature for enterprises to strengthen their competitive position (Kenneth, 2011).

This paper will identify matrix strategies on how product knowledge can be used during design and how it can improve the quality of a product, in a perspective of how such

Copyright (C) 2012 BOCA, Gratiela Dana. This is an open access article distributed under the Creative Commons Attribution License unported 3.0, which permits unrestricted use, distribution, and reproduction in any medium, provided that original work is properly cited. Contact author: BOCA, Gratiela Dana E-mail: bocagratiela@yahoo.com 
strategies and applications can improve a product.

Until few years ago, the process of product design and development was basically focused on defining the characteristics that a product should have in order to make it, the correct response to certain functional specifications, the latter often being defined by restrictions imposed by manufacturing processes.

The manufacturing costs are reduced and also the life cycle and product reliability are increasing along the life cycle of the product.

There is a given classification of knowledge in two dimensions: recognized, unrecognized knowledge and codified - tacit knowledge (Yoshikawa 1993).

Besides, two types of design knowledge are identified:

1. Design process knowledge (which describes HOW)

2. Design object knowledge (which is largely fact knowledge to describe WHAT).
A design process begins with ambiguous or rough descriptions of the design object and the product will be gradually detailed and completed.

\section{Application Examples - A Study Case}

The paper presents the Matrix for product development process and defines the quality factors for a new generation products and the importance from economical point of view of the design stage in the manufacturing process (Figure 1).

The Product Development Process identifies also the interaction between the economy and the environmental management of knowledge product, taking in consideration the internal and external factors which can influence the entire process low design noise, security product and costs.

The Matrix shows the optimal way for knowledge product and the possibilities for designer to identify new solution for new friendly environmental products.

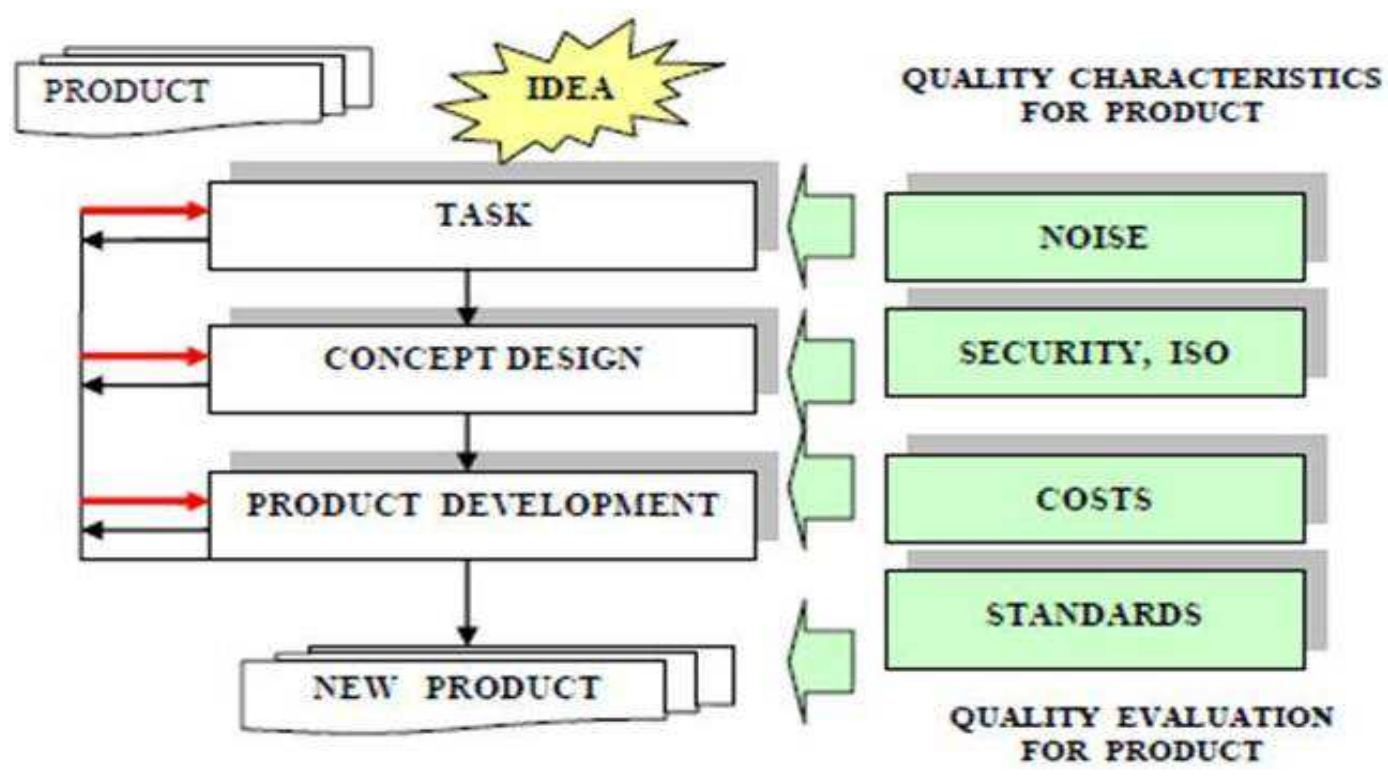

Fig. 1. Knowledge Management Product Development Process 
The tools used in research work to identify the strategies for product knowledge management are the simulation programs (CAD, Pro-Engineering, ANSYS, TOSCA) used by economical systems to create new products, to get better constructive solution from the design faze of the product, and to identify the damages and the future failures of products.

However, the design process is now contemplated from a wider perspective: instead of merely referring to the products own characteristics, it now takes into account external factors such as:

- Customers requirements;

- Quality;

- Reduction of manufacturing costs and controls;

- The assembly and distribution process;

- Environmental impact before and after manufacture;

- Product disassembly reuse and recycling;

- Safety,

- Low design frequency,

- Ergonomic factors.

These factors must be taken into account from the very conception of the product, in order to satisfy the dynamics of ever more competitive markets regarding price, quality and time to market new products.

The changing demands of customers must also be satisfied, a factor involving new social perceptions, like concern for the environment.

All this has a direct effect on the way in which products must be designed, produced and recycled and introduces new ways of looking at the Product Development process - design included of course- as well as at the techniques and technologies involved (Guequig, 2010).

The implications of this new perspective on design are important because the new product must satisfy numerous criteria simultaneously.

These criteria must be taken into account during the conception of the product.

The synergies and restrictions that may exist between them during the entire life of the product must be analyzed.

As a result, the designer can no longer act in an isolated fashion; instead he must interact with many other specialists both inside and outside the company in order to define the different criteria that characterize a product (Pahl 1993).

Design and manufacture characteristics are considered basic information to be handled jointly and simultaneously during the design process.

The strategy for knowledge product makes the difference of Product Design from Mechanical Engineering, the latter is primarily involved with the application of analysis and scientific theory to the design of engineering systems (Hubka, 1996).

Typically, pure engineering problems do not have product's appearance or use by humans as primary concerns.

On the other hand, Product Design is involved in products where these issues and their interaction with the internal technology are critical to the success of the product.

These activities help ensure maximum effectiveness in developing the design process, thereby enabling tasks to be undertaken that otherwise would not be carried out. 
Effective Design Engineering can improve the following three important parameters of the company's competitiveness: enhance quality, cut costs and speed up time -to- market (Fricke, 1996).

The types of companies to which design and development techniques are best applied are those which design and manufacture their own products, and in which competitiveness is described by factors such as:

- Quality;

- Price;

- Functionality;

- Development Time;

- Commercialization Time.

Furthermore, if a company is to apply these techniques, it must have a well-defined operating structure, not to mention the necessary human and technical resources to implement and use the techniques.

Should this not be the case, the implementation and use of these techniques will yield few benefits.

A competitive product must address factors such as: cost, performance, aesthetics, schedule or time-to-market and quality.
The importance of these factors will vary from product-to-product and market-tomarket and over time, customers or users of a product will demand more and more, more performance at less cost (Figure 2).

The model of knowledge process sustains the organization decision to manufacture a product and its properties during the product life cycle (Klepper, 2005).

The organization disturbances influence the future orientation taking in consideration the new trend of green products will make a challenge for discovering new solutions and change management for environmental management process (Dankwort, 1996).

The variable affecting the product environment are sounds, durability, reliability, safety and quality variables characteristics which affect the product, the knowledge of infrastructure design important to the extension of knowledge product (Dietz. P., 1997).

Modeling of knowledge process is a way to describe mainly the content of information concerning the product and the usage of system functionality with regard to each stage of design/ development, but taking in consideration the knowledge product (Figure 3). 


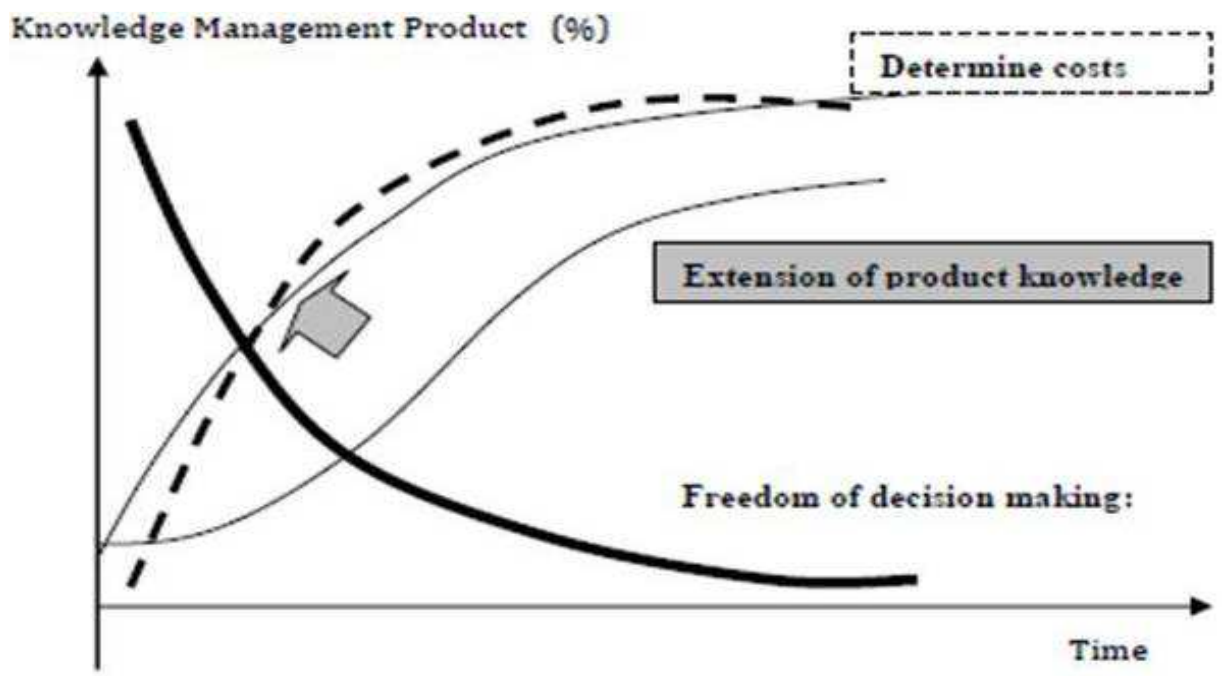

Fig.2. Extension of Knowledge Management Product through the Use of Information Technology

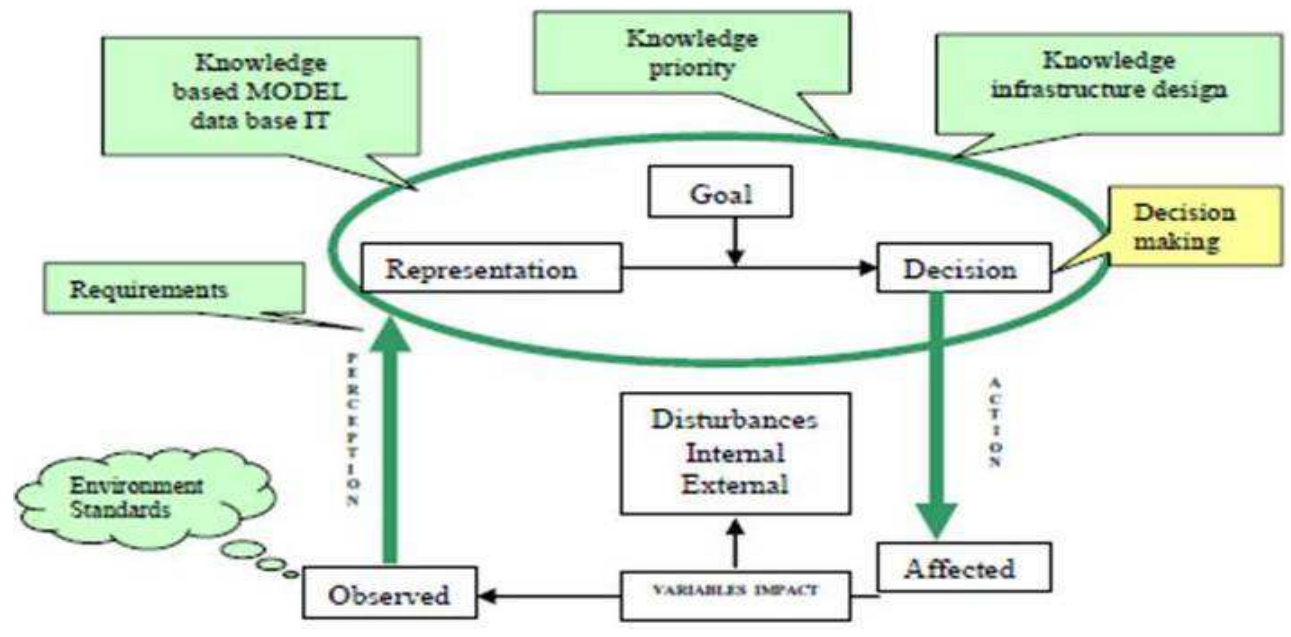

Fig.3. A Model for Knowledge Management in Product Process

The knowledge - making decision step is important as an input variable for the manufacture system; for that reason the research is concentrated on identifying the matrix strategies for technological process and allows the designer the possibility to be able to select from different knowledge infrastructure designs the optimal model (Dietz, P., 1996).

The paper focuses on selection importance of description of handled engineering knowledge with respect to information content and usage during life cycle knowledge product ( Klepper, 1993).

Between the observed and affected variable, the impact can influence the final decision of designer, because the knowledge-based model must harmonize with the new laws and rules regarding the environment and the green friendly products (Weber, 1996). 
Taking in consideration the model, the paper is trying to select and present some useful tools for organization to reduce the costs, to assure eco products and to increase the reliability and quality products.

The new tools are computer programs which are using the finite element method, programs who can give a virtual simulation of the product in order to realize first, a virtual work place of product with possibility to change in function of the customer needs and utilities and the quality and reliability characteristics of the product.

Figure 4 presents the information hole for a designer and how information for product management manufacture can influence the engineer decision in production process so as to identify the knowledge product process important for the organization to identify in a short time and from an economical point of view the best solution for manufacture production process (Boca, 2012).

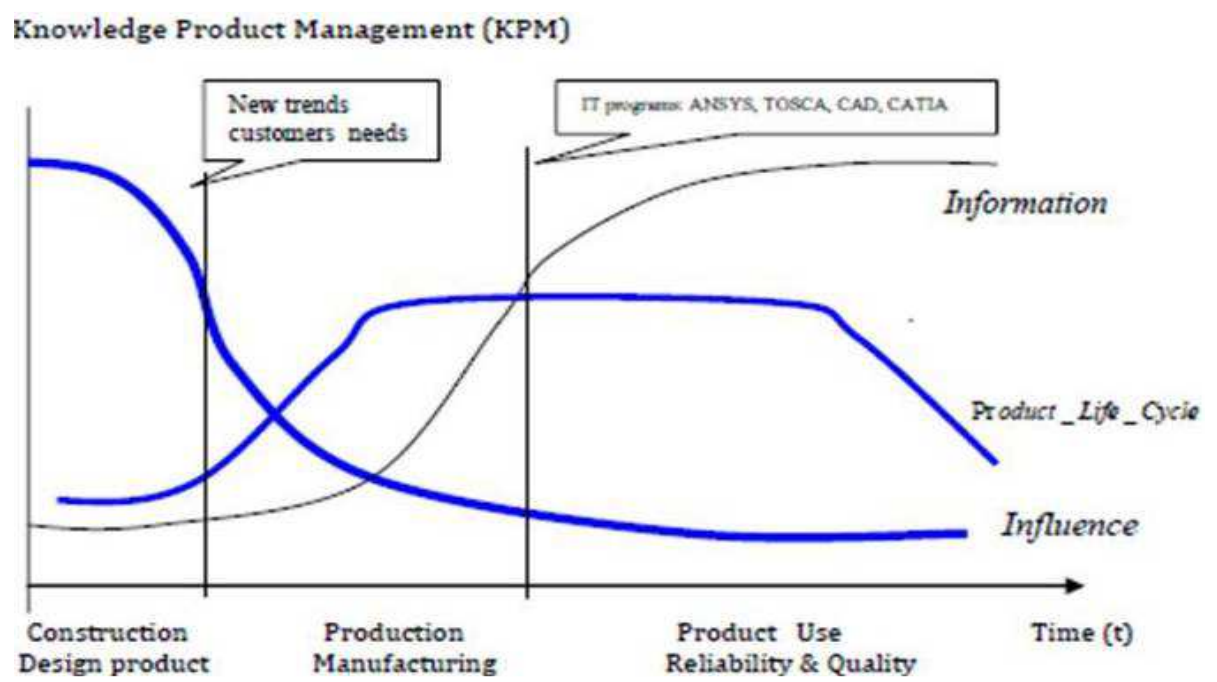

Fig.4. The Knowledge Management Information in Life Cycle Product Hole of the Designer

\section{Results}

The tools used in this research work to identify the strategies for product knowledge management are the simulation programs (CAD, Pro-Engineering, ANSYS, TOSCA) used by economical system to create new products, to get better constructive solution from the design phase of the product, and identify the damages and the future failures of products (Andrestsch, 2000 ; Baya, 1994).

A view in figure 2 describes the way to look at the product and its properties during the product life cycle from an economical point of view regarding the quality costs but also from knowledge product information on the enter-management of manufacturing process.
In this way, the researchers can describe mainly the content of information concerning the product and the usage of system functionality with regard to each stage of product design from the first stage until the development (Krause, 1994).

Designers will be able to define, using the Quality Matrix, some strategies for implementation of new orientation in technological process (table 1).

Each program presents in the matrix will have positive reaction upon the costs and time manufacture of the products, that means a higher quality for total quality management of the entire system from an 
economical point of view and also from engineering possibilities to select the variable characteristics and parameters of products (Lenau, 1989).

Making use of a matrix representation, the scope of the applications can be represented.

The table indicates clearly the heavy loaded vertical axis of the product property class requirements and shows the importance of an integrated requirement management.

The Matrix presents also different evaluation of using FEM programs with different programs and the influence upon the life cycle of the product, especially in the design stage of technological manufacturing.
In compliance with the various approaches, it seems that the matrix representation considering product properties and life cycle is quite suitable to represent engineering knowledge handled in the systems (Table 1).

Having products with a more or less complete product description, the designer is able to extract such interrelationships manually and to use them when he is going to make improvements to his products or to create new products, i.e. using the experience and knowledge of already concluded designs.

In this case, the designer is able to profit from feedback in far earlier phases.

Table 1: Description of Engineering Knowledge and Usage during Life Cycle Product

\begin{tabular}{|c|c|c|c|c|c|c|}
\hline \begin{tabular}{|l|} 
Product Life Cycle \\
Product Property \\
\end{tabular} & $\begin{array}{l}\text { Product } \\
\text { planning }\end{array}$ & $\begin{array}{c}\text { Conceptual } \\
\text { design }\end{array}$ & $\begin{array}{c}\text { Final } \\
\text { design }\end{array}$ & $\begin{array}{l}\text { Detail } \\
\text { design }\end{array}$ & $\begin{array}{l}\text { Productio } \\
\mathrm{n} \text { planning }\end{array}$ & $\begin{array}{c}\text { Productio } \\
\mathrm{n}\end{array}$ \\
\hline $\begin{array}{l}\text { Organization } \\
\text { Departments }\end{array}$ & $\begin{array}{l}\text { Management } \\
\text { Production }\end{array}$ & $\begin{array}{l}\text { Engineering } \\
\text { Design }\end{array}$ & $\begin{array}{l}\text { Engineering } \\
\text { Design }\end{array}$ & $\begin{array}{l}\text { Engineering } \\
\text { Design }\end{array}$ & $\begin{array}{l}\text { Managemen } \\
\mathrm{t} \\
\text { Production }\end{array}$ & $\begin{array}{l}\text { Engineering } \\
+ \\
\text { Managemen } \\
t\end{array}$ \\
\hline $\begin{array}{l}\text { customers } \\
\text { requirements }\end{array}$ & $(2)(5)(6)$ & $\begin{array}{c}(1)(2)(5)(6 \\
)\end{array}$ & $\begin{array}{l}(1)(2) \\
(5)(6)\end{array}$ & $(1)(5)(6)$ & (5) & (5) \\
\hline $\begin{array}{l}\text { product } \\
\text { requirements }\end{array}$ & (5) & $(2)$ & (2) & (5) & (5) & $(5),(6)$ \\
\hline functions & (5) & $(2)$ & $(2)$ & & (5) & \\
\hline $\begin{array}{l}\text { solution } \\
\text { principles }\end{array}$ & $(6)$ & & $(1)(3)(6)$ & $(1)(3)(6)$ & & \\
\hline geometry & & & $(1)(3)$ & $(1)(3)$ & & \\
\hline tolerances & (6) & & $(3)(6)$ & $(3)(6)$ & & \\
\hline materials & (6) & & $(4)(6)$ & $(4)(6)$ & (4) & (4) \\
\hline $\begin{array}{l}\text { manufacturing } \\
\text { methods }\end{array}$ & & & (3) & (3) & (5) & (5) \\
\hline $\begin{array}{l}\text { strength and } \\
\text { durability }\end{array}$ & (5) & (5) (6) & $(1)(3)(4)$ & $(1)(3)(4)$ & (4) & (4) \\
\hline costs & (5) & & $(4)$ & (4) & (5) & (5) (6) \\
\hline time & (2) & (2) & $(2)(3)$ & $(2)(3)$ & (2) & \\
\hline usage properties & & & (3) & (3) & & \\
\hline $\begin{array}{l}\text { environmental } \\
\text { properties }\end{array}$ & $(5)(6)$ & $(5)(6)$ & $(5)(6)$ & & $(5)(6)$ & \\
\hline
\end{tabular}

1- PRO-Engineer, (2) - CAD, (3) - ANSYS, (4) - TOSCA- product optimization , (5)- DEMAND, (6) - PRODUCT DESIGN

The new provocation for designer will be to establish the connection and choose the best solutions and suitable programs for product, taking in consideration the matrix and learning from each evolution of the cycle design and applying the best solution. 
Therefore, the nearest goal is to build up such retrieval strategies so the designer could search for situations similar to his current stage, products with comparable properties, information on a specific life cycle phase; obtain immediately information about the previous product damages and failures and identify the possible quality improvements.

So, he can look after related results, possible solution for his product problem and decide which strategy is suitable for his situation.

That is why the designer will have the opportunity to select either one or more of the proposed support actions to discover the most suitable one.

It might also be that he will go another way in problem solving as a consequence he must have the possibility to go and follow a new model interactively, such as a new way case and develop a new strategy and a new data base (Dörner 1979).

The most suitable solution will be detected and initiated by the system. This may be a disputable strategy.

In the beginning, when a product is developed from scratch, ideally no experience at all exists for this new product but having the information about the knowledge product management is possible to obtain the quickly solution and define a new shape and innovate the product from different stages of his life cycle.
The designer will enter each phase of the development trying to make optimal decisions for the future. Only when a phase is finished or the product is already in use and when he observes possible drawbacks in the handling of his product, he may be able to connect those drawbacks (the symptom) to decisions in some phases (the cause) he had made.

Simple knowledge is represented as plainstructured data, whereas complexity grows with relationships, such as rules or formulae unto interactively working (system) processes triggered by design activities.

Analysis methods are slightly under represented because there are a lot of powerful application engineering problems:

- FEM systems;

- Calculation programs for various mechanical components;

- Tools for kinematic simulation that are not part of the systems itself.

There seems however, to be a lack of applications concerning process-oriented information for the final decision for new products like in Table 2. Taking in consideration the same programs for product simulation in the first stage of design using (1) - PRO-Engineer, (2) - CAD, (3) - ANSYS, (4) - TOSCA, (5) - DEMAND, (6)- PRODUCT DESIGN, we can compare the program solutions and select in function of the needs and utilities of the customer. 
Table 2. Complexity of Product Knowledge Life Cycle and the Impact in Knowledge Management

\begin{tabular}{|c|c|c|c|c|}
\hline$(1)(2)(3)(4)(5)(6)$ & $(1)(2)(3)(4)(5)(6)$ & $(1)(2)(3)(4)(5)(6)$ & $(2)(4)$ & $(2)$ \\
\hline $\begin{array}{l}\text { Structured data } \\
\text { description of the } \\
\text { product } \\
\text {-customer needs } \\
\text {-product utility }\end{array}$ & $\begin{array}{l}\text { Rules } \\
\text {-design } \\
\text {-product } \\
\text { characteristics } \\
\text {-costs }\end{array}$ & $\begin{array}{l}\text { Functions } \\
\text {-customer } \\
\text { description }\end{array}$ & $\begin{array}{l}\text { Analysis methods } \\
\text {-IT programs FEM } \\
\text { method } \\
\text {-changes of } \\
\text { variables } \\
\text {-TOSCA- } \\
\text { optimization } \\
\text { program }\end{array}$ & $\begin{array}{l}\text { Connected } \\
\text { processes } \\
\text {-data base }\end{array}$ \\
\hline
\end{tabular}

The durability of knowledge in terms of time means the amount of changes that take place on the product data based along the long life cycle of product..

Cost will become a more important factor in the acquisition of a product in two situations:

1. First, as the technology or aesthetics of a product matures or stabilizes the competition is increasingly based on cost or price.

2. Second, a customer's internal economics or financial resource limitations may shift the acquisition decision toward affordability as a more dominant factor. In either case, a successful product supplier must focus more attention on managing product cost.

Reasons for the failure of new products:

- Underestimation of competitors;

- Overestimation of the number of potential consumers;

- Overestimation of the price of the product;

- Lack of or failure to identify mature markets for the distribution of the product.

\section{Conclusions}

This paper has introduced a selection of design support relevant to product knowledge management.
This includes the knowledge representation, modeling and the strategies of how to make use of this knowledge for the sake of design support.

This view on knowledge management strategies indicates the level of modeling and the complexity of application a system designer has to think about.

A design support system has to accept decisions taken by a designer (and might be allowed to propose solutions as well).

It is state of the art to document what decision has been made (every simple program and tool has an undo functionality) to document, how something was decided not only what (design object) and how (design process), but also why something has been decided.

Still, design is a creative process and some decisions might be arbitrary because it is important to document them for being the ones to be reconsidered first in cases of dissatisfaction.

Documenting why something has been decided is also important for possible feedback strategies to make design processes comprehensible.

Generally, this means that design support systems could help the designer in the way he is working right now, otherwise it will be rejected. 
In contradiction to that Quality Matrix, the new innovation often requires new thinking and sometimes this new thinking or methodology affects the users, because the need of information about knowledge product management.

Although this paper is not primarily concerned with this topic, but the paper would like to point out that a product and user interface of computer programs need to follow the new results of industrial sciences and ergonomic studies which required new friendly products, taking in consideration the strict requirements of international standards.

These results in strategies knowledge management structures can bring a competitive advantage for the companies that use this Quality Matrix as a solution.

The new matrix and its methods used in design product will help customers to:

- Make early decision in the design cycle;

- Reduce the product development cycle;

- Improve time-to -market;

- Reduce design and manufacturing cost;

- Reduce design cycle;

- Reduce cost of materials;

- Reduce number of prototypes;

- Reduce number of physical testes.

The extension of product knowledge management bring also

- Early support for expert knowledge;

- Knowledge generation and confirmation through simulation and virtual design;

- Reduce the analytical calculation;
- Information representation;

- Feedback from product life cycle;

- Evaluation and optimization methods;

- Decision support;

- Evaluation and optimization methods.

The final conclusion is the sign with the new stamp for product knowledge TECH -ECOSTAMP

T-technology

E-economy

C-cost

H-harmonization

E-environment

C-costumer

O-opportunity

$\boldsymbol{S}$-select

T-time

A-adapt

M-management

$\boldsymbol{P}$-production

\section{Acknowledge}

The paper presents the results obtain under the research grant sponsor by European ERASMUS Grant, the topic of research was to define and identify solutions to improve quality management of the organization, reengineering work process, flexible manufacturing system which has one thing in serving the customer. The enter work was realized in Technical University from Clausthal, Germany, IMW Clausthal, under the supervision of Prof.Dr. Peter DietzPhD.Hc. 


\section{References}

Audrestsch, D. B. \& Klepper, S. (2000). Innovation, Evolution of Industry and Economic Growth, Amertech Foundation Research ISSN00-3.

Baya, V. \& Leifer, L. J. (1994). 'A Study of the Information Handling Behavior of Designers during Conceptual Design,' International Conference on Design Theory and Methodology (DTM '94). Minneapolis, DE-Vol. 68, American Society of Mechanical Engineers (ASME), pp. 153-160.

Boca,G. D. (2012). 'A Quality Matrix for Product Knowledge Management-Feedback Design,' Technological Management Review, Vol 1/2012, North University of Baia Mare pp:12-17.

Dankwort, C. W. \& Podehl, G. (1996). "Industrial CAD/CAM Application and System Architecture - A Closed Loop," I. Horvathand K. Varadi (eds.): International Symposium on Tools and Methods for Concurrent Engineering (TMCE '96). Budapest 29-31 May 1996, pp. 206-211.

Dietz, P. \& Ort, A. (1996). 'Verwendung von Wiederholteil-und Normteilkatalogen gemäß der ISO 13584,' "Parts Library" unter besonderer Berücksichtigung der Anforderungen in der Konstruktion.VDI (ed.): Effiziente Anwendung und Weiterentwicklung von CAD/CAMTechnologien.München, VDI Berichte 1289, VDI Verlag, pp. 399-408.

Dietz, P., Penschke, S. \& Ort, A.(1997). 'Ansätzezur Parallelen Gestaltung von Produkten und Fertigungsprozessen,' VDI(ed.): Features verbessern die Produktentwicklung - Integration von Prozessketten.Berlin 20./21. Februar 1997, VDI Berichte 1322, VDI Verlag, pp. 313-329.

Dörner, D. (1979). 'Problemlösen als Informationsverarbeitung,' 2. Aufl., W. Kohlhammer Verlag Stuttgart.
Fricke, G. (1996). "Successful Individual Approaches in Engineering Design," Research in Engineering Design 8, pp.151-165 p].

Guequig, L. \& Zhongliang, C. (2010). 'Dynamic Industry Evolution Model on Product Life Cycle,' IACEED 2010, Published by Elsevier Ltd.

Hubka, V. \& Eder, W. E. (1996). 'Design Science- Introduction to the Needs, Scope and Organization of Engineering Design Knowledge,' Springer Verlag Berlin Heidelberg New York.

Kenneth L. Simon (2011). "Product Market Characteristics and Industry Life Cycle," Economics Department, Rensselaer, 110 8th Street, Troy, NY 12180, USA.

Klepper, S. (1996). "Entry ,Exit, Growth and Innovation over the Product Life Cycle," The American Economic Review, Vol.86, No. 3., pp. 562-583.

Klepper, S. \& Kenneth L. Simons (2005). "Industry Shakeouts and Technological Change," International Journal of Industrial Organization 23(1-2), February. pp.23-43.

Klepper, S. \& Simons, Kenneth, L. (1993). 'Technological Change and Industry Shakeouts,' Carnegie Mellon University .

Krause, F. L., Hayka, H. \& Jansen, H. (1994). 'Produktmodellierung als Basis für eine wettbewerbsfähige Produktentwicklung,' J. Gausemeier (ed.):CAD'94Produktdatenmodellierung und Prozeßmodellierungals Grundlage neuer CAD-Systeme, Fachtagung der Gesellschaft für Informatik(GI). Paderborn 17./18. März 1994, Carl Hanser Verlag, pp. 29-54.

Lenau, T. \& Alting, L. (1989). "Intelligent Support Systems for Product Design," Annals of the CIRP Vol. 38 1, pp.163-166.

Pahl, G. \& Beitz, W. (1993). 'Konstruktionslehre- Methoden und 
Anwendung,' 3., neubearb. u. erw. Aufl., Springer Verlag Berlin Heidelberg New York.

Pham, D. T. (ed.) (1991). 'Artificial Intelligence in Design,' Series: A. Kusiak (ed.): Artificial Intelligence in Industry. Springer Verlag Berlin Heidelberg New York.

Weber, C. (1996). 'What is a Feature and What is its Use? - Results of FEMEX Working Group I,' International Symposium Automotive Technology and Automation (ISATA). Florence, pp. 287-296.

Yoshikawa, H. (1993). "Systematization of Design Knowledge," Annals of the CIRP Vol. 421 , pp. 131-135. 


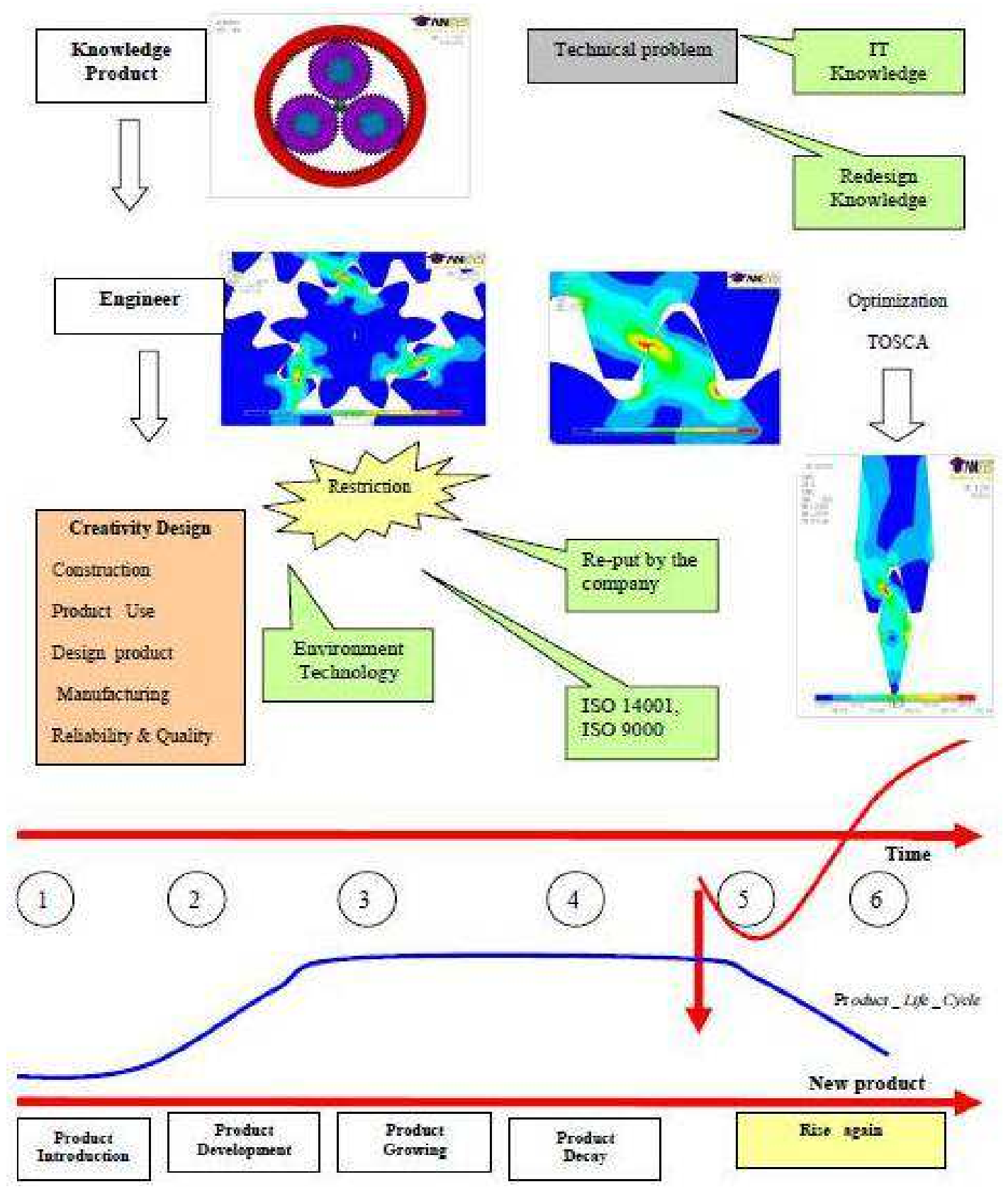

Life Cycle Product Model for Knowledge Management and Manufacturing Design (Author's idea) 